Vesna Gotovina*

\title{
Archival Materials of the State Authorities Related to the Processes of Democratisation and the Attainment of Independence of Slovenia
}

\author{
IZVLE $\check{C} K$ \\ ARHIVSKO GRADIVO DRŽAVNIH ORGANOV O PROCESIH DEMOKRATIZACIJE \\ IN OSAMOSVAJANJA SLOVENIJE
}

Večji del arhivskega gradiva o procesih demokratizacije in osamosvajanja Republike Slovenije se še vedno hrani pri ustvarjalcih ali imetnikih arhivskega gradiva. Arhivska zakonodaja predpisuje, da se gradivo izroča najkasneje trideset let po nastanku. Zato avtorica v prispevku opozarja tudi na nekatere nevarnosti, ki ogrožajo arhivsko gradivo, še neprevzeto v pristojne arhive.

Ključne besede: arhivsko gradivo, osamosvojitev Slovenije, dostopnost arhivskega gradiva, ohranjenost arhivskega gradiva

\section{ABSTRACT}

The major part of the archival materials related to the processes of democratisation and the attainment of independence of the Republic of Slovenia is still in the custody of the creators or holders of the archival materials. According to the archival legislation the materials are to be submitted to the archives not later than thirty years after their creation. Therefore the author of this contribution also points out various threats endangering the archival materials which are yet to be acquired by the competent archives.

Keywords: archival materials, attainment of independence of Slovenia, accessibility of archival materials, preservation of archival materials

* Head, Sector for the Protection of Government Administration Records after 1945, Ministry of Culture of the Republic of Slovenia, Archives of the Republic of Slovenia, Zvezdarska 1, SI-1127 Ljubljana, vesna.gotovina@gov.si 


\section{Introduction}

One of the basic tasks of the Archives of the Republic of Slovenia is the preservation of the archival materials produced by the highest state administration, justice administration and legislative bodies during the implementation of their functions.

What are archival materials? Archival materials are documentary materials with a long-term importance for history, other sciences and culture, or for the legal certainty of individuals; they constitute a cultural monument. ${ }^{1}$ Since the attainment of independence this definition has been extended in the part referring to the "long-term importance for the legal certainty of individuals". In Slovenia the public archival materials are kept in the national archives (the Archives of the Republic of Slovenia), regional archives (regional and historical), and archives of the local self-governing communities.

As archivists who appraise documentary materials on the basis of archival principles and appraisal criteria governed by law ${ }^{2}$, we keep asking ourselves which contents and sorts of documentary materials - produced in extreme quantities in this day and age - should be preserved for the next generations. The burden of responsibility has become even heavier as our historical period represents a turning point and we ourselves, in a certain way, also shape the image of the times we live in. We are well-aware of this extremely important mission. Therefore the materials produced by some of the most important bodies in relation to the most important events from the period of the attainment of independence and democratisation of Slovenia are almost entirely defined as a cultural monument (the condition of the materials is also taken into account). ${ }^{3}$

The archivists who cooperate with the creators of the archival materials have to prepare "written expert instructions on the selection of archival materials from documentary materials" for each public body and update these instructions each time the body is restructured. Completely new expert instructions have to be prepared in the event of a major restructuring of the administration. ${ }^{4}$ With the entry into force of the Decree on Administrative Operations in 2005, documentary materials gain the

1 ZVDAGA, Article 2.

2 ZVDAGA, Article 40. The criteria for evaluation: requirements of historiography, other sciences and culture; needs of persons for permanent legal certainty; importance of the contents of the materials; specificity of events and phenomena at a certain point in time; specificity of places or regions; importance of public bodies; importance of the author; significance of the materials from the viewpoint of cultural diversity; originality of documents and their duplication (the materials most perfectly reflecting the contents are specified); originality of data and information; representative selection - samples; condition and volume of materials created; intrinsic and external characteristics of the materials (language, artistic value, means of recording); other criteria as specified by the competent archives.

3 For example, all materials kept by the Ministry of Defence have been declared as archival materials up to and including 1991. The materials, created during the operations of the Presidency of the Republic of Slovenia, will be treated in a similar manner.

4 These are always reviewed by commissions. Commissions consist of the members of the competent archive and the public body for which the expert instructions are being verified. 
status of archival materials even before they are actually created. ${ }^{5}$ Archival materials are acquired by archives in the original form, without any technological limitations, arranged, registered, in comprehensive and complete sets and in accordance with the technical provisions. Selecting and accessioning archive materials in digital form represents a specific challenge for the archival science, as it requires additional efforts in order to maintain accessibility, usefulness, integrity, authenticity and sustainability in comparison with the materials in paper (physical) form.

Therefore the archival legislation lays down additional expert and technical instructions for the selection of digital materials.

\section{Archival Fonds and Types of Archival Materials of Public Authorities}

Immediately after the attainment of independence of Slovenia we began to acquire the archival materials produced until 1990 by the administrative ${ }^{6}$ and other bodies that were abolished at that time.

\subsection{The most important archival fonds bearing witness to the processes of democratisation and the attainment of independence}

Researchers and other users of archival materials can access the basic data on archival fonds that are already registered in guides. They are published on the websites of the relevant archives and updated regularly. Therefore this contribution only states some of the most important fonds and collections for:

\subsubsection{Political history research:}

- Government of Slovenia ${ }^{7}$ (1945-1992). Transcriptions of the first government are not open for research. Access to these materials is subject to approval by the Government of the Republic of Slovenia following a proposal from the archival commission.

- Assembly of Slovenia ${ }^{8}$ (1943-1990). The materials are accessible in their entirety with the exception of submissions and appeals containing protected personal data.

- Presidency of Slovenia9 (1974-1990). The materials are accessible in their entirety with the exception of applications and appeals of individuals and data on clemencies granted to prisoners.

5 Filing plans with retention periods and provisions on the archival materials are implemented in the information systems for the management of documentary materials.

6 E.g. the Republic Committee for Veterans and Disabled Servicemen, materials of the self-management communities of interest, etc.

7 SI AS 223.

8 SI AS 1115.

9 SI AS 1944. 
- Republic Electoral Commission ${ }^{10}$ (1963-2000). The materials are accessible in their entirety. They also comprise data on the first multiparty elections, the elections of the Presidency of the Republic of Slovenia in 1990, and the presidential elections in 1992.

- The collection on plebiscite of $1990 .{ }^{11}$ The materials are accessible in their entirety. All documentation related to the plebiscite and its implementation has been declared a cultural monument.

- Government of the Republic of Slovenia Public Relations and Media Office ${ }^{12}$ (1972-2001). The materials are accessible in their entirety.

- Protocol Service of the Republic of Slovenia (1945-1991). ${ }^{13}$ The materials are accessible in their entirety.

- Office of the Government of the Republic of Slovenia for National Minorities ${ }^{14}$ (1974-2012). The materials contain protected personal data.

- Office of the Republic of Slovenia for Immigration and Refugees ${ }^{15}$ (1974-2012). The materials contain protected personal data.

- Council for the Protection of Human Rights and Fundamental Freedoms ${ }^{16}$ (1987-1995). The materials contain protected personal data.

- Commission for Relations with Religious Communities ${ }^{17}$ (1953-1991). The materials contain protected personal data.

2.1.1 Economy, agriculture and transport research:

- Agency for the Audit of the Ownership Transformation of Companies ${ }^{18}$ (19932004);

- Social Accounting Service ${ }^{19}$ (1974-2002);

- Ministry of Transport and Communications ${ }^{20}$ (1975-1996);

- Court of Audit of the Republic of Slovenia ${ }^{21}$ (1987-2003);

- Ministry of Economic Relations and Development ${ }^{22}$ (1994-2002);

- Ministry of Finance ${ }^{23}$ (1945-1993);

- Republic Committee for Agriculture, Forestry and Food of the Socialist Republic of Slovenia ${ }^{24}(1972-1991)$;

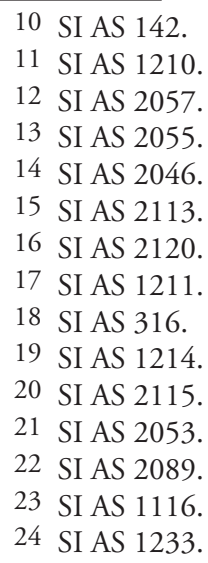


- Republic Committee for Industry and Construction of the Socialist Republic of Slovenia 25 (1965-1991);

- Farmland and Forest Fund ${ }^{26}$ (1918-2014);

- Slovenian Roads Agency ${ }^{27}$ (1967-2008).

2.1.2 Culture, education and science research:

- Ministry of Education, Science and Sport of the Republic of Slovenia ${ }^{28}$ (19672004). The materials contain protected personal data.

- Slovenian Research Agency ${ }^{29}$ (1986-2005);

- Ministry of Education and Sport ${ }^{30}$ (1982-2003). The materials contain protected personal data.

\subsubsection{Defence policy research}

The Archives of the Republic of Slovenia signed an agreement with the Ministry of Defence of the Republic of Slovenia on the extension of the deadline for the submission of the archival materials older than 30 years until 31 December 2025 at the latest. That is the reason why the majority of these materials is not yet available to the public. The relevant Ministry departments are continuously cooperating with the Archives, arranging and describing the materials according to the instructions in order to complete the transfer.

\section{Arrangement of Documentary and Archival Materials}

\subsection{Arrangement of the materials in the custody of creators and holders}

With the establishment of the new state, administrative operations ${ }^{31}$ continued in the context of individual government departments and did not involve any such significant changes as might have been expected. We can merely observe that the bodies were repeatedly renamed in a very short period of time. ${ }^{32}$ These kinds of changes usually cause problems for archivists when it comes to the creation of fonds. ${ }^{33}$ We can point out the clerical operations in the Assembly of the Republic of Slovenia as

25 SI AS 1265.

26 SI AS 2133.

27 SI AS 2079.

28 SI AS 2003.

29 SI AS 2033.

30 SI AS 2026.

31 Vladimir Žumer, Poslovanje z zapisi. Upravljanje in hramba dokumentarnega gradiva, klasifikacijski načrti za razvrščanje gradiva z roki hrambe in elektronska hramba gradiva $v$ digitalni obliki (Ljubljana: Planet GV, 2008).

32 For example Republic Committee for Education, Schooling and Physical Culture (16 May 1990 - 22 June 1990), Republic Secretariat for Education, Schooling and Physical Culture (23 June 1990 - 27 June 1991) and Ministry of Education and Sport (28 June 1991 - 14 May 1992).

33 Archival fonds is the archival material, created during the operations of a single legal entity, natural person or family. 
an extremely interesting example of administrative operations. Despite the change of the state regime and the transition from the delegate system to the multiparty system, session documents are the only materials we are able to classify according to terms of office - to the period before and after the first multiparty elections. The materials pertaining to the legislative procedure or the adoption of laws are arranged according to the contents of acts until 2008, regardless of the terms of office. Therefore we are not able to differentiate between the legislative procedure materials of the Assembly of the Republic of Slovenia and the National Assembly, established in 1992. Similar also applies to the operations of the other highest administrative and state bodies. As it is evident from the already acquired archival fonds, we have not decided to classify the fonds according to the period before and after the establishment of the Republic of Slovenia. The process of the dissolution of Yugoslavia and recognition of Slovenia was not a momentary, instantaneous event which would cause major and radical changes in the operations of the state authorities. The most profound and expected changes are apparent only in the administrative operations of the new ministerial fields of defence and foreign policy.

The quality of documentary and archival materials arrangement fell alarmingly precisely during the processes of democratisation and attainment of independence. Since 1962 the materials were classified ${ }^{34}$ according to the content and on the basis of the prescribed filing plan. This plan became inadequate already at the end of $1980 \mathrm{~s}$ and in the beginning of 1990s in terms of contents, especially due to the old, so-called socialist terminology (e.g. socio-political organisation, self-management, etc.). Therefore the existing filing plan was quickly abandoned, and public authorities were left to their own devices and innovativeness in clerical operations. For quite some time no one in the state was concerned with clerical operations and documentary materials management despite the warnings, expressed by the archives, that such treatment greatly endangered archival materials. ${ }^{35}$ Some state authorities even went so far in their operations that they completely abandoned classification when they introduced electronic registers. They were convinced that with modern technology it would be possible to search for data directly in the contents, which turned out to be completely inappropriate. The global expansion of electronic services also resulted in the emergence of the international standards ${ }^{36}$ for the management of documentary materials. Slovenia re-established the single filing plan for public authorities in $2005^{37}$. The period of incoherent and inconsistent classification of materials according to the contents in the public administration thus lasted approximately fifteen years. This means

34 Rajka Bućin, Klasifikacijski sustavi u spisovodstvu uprave. Povijesni razvoj i suvremena stremljenja (Zagreb: Hrvatski državni arhiv, 2015), 176-241.

35 Vesna Gotovina, "Sistemi poslovanja s spisi v Sloveniji od leta 1955 dalje," Arhivi 16, No. 1-2 (1993): 53.

36 ISO 15489 - Information and documentation - Records management.

37 Vladimir Žumer, "Klasifikacijski načrti za razvrščanje dokumentacije z roki hranjenja," in: Tehnični in vsebinski problemi klasičnega in elektronskega arhiviranja, eds. Ivan Fras and Nina Gostečnik (Radenci, 2013), 353-68. 
that we shall encounter major problems when selecting and accessioning the archival materials for the archives. Even today it is apparent that the materials from the period of the attainment of independence are poorly preserved. For example, there are no transcriptions, stenographic records, etc. in the session documents files of the most important state authorities. It is very likely that many problems will also arise with regard to the preservation of sound recordings. The administrative operations of the highest state authorities were unsupervised for almost fifteen years. Even today only the archives and the Culture and Media Inspectorate of the Republic of Slovenia deal with this matter. Between 2007 and 2015 only two preventive inspections ${ }^{38}$ of documentary and archival materials management were performed at all the ministries. Until 2006 the archival legislation did not include penal provisions for damaging or destroying archival materials. These provisions were only enforced with the Protection of Documents and Archives and Archival Institutions Act, but the penalties for infringements involving the non-implementation of the Act are merely symbolic. ${ }^{39}$

\subsection{Arrangement of archival materials in the Archives of the Republic of Slovenia}

In the past decades the archives acquired many archival materials which were not properly arranged and registered, especially due to the prevailing opinion that it was best to keep such materials safe in the archives as well, as they could be destroyed in the custody of creators and holders due to inappropriate handling. In view of the bad experience with the materials of the predecessors of the Ministry of the Interior and the intelligence services, such decisions were relatively justified. Nonetheless, the archival materials which have not been arranged and registered in detail represent a great burden for the archivists who work with the more recent materials. The quantity of these materials is vast, therefore the expert arrangement and description processes are exceptionally slow.

\section{Accessibility of Archival Materials}

Slovenia has one of the most liberal policies with regard to accessing the archival materials already kept in the archives. ${ }^{40}$ Researchers can use the materials free of charge which is rather uncommon in the majority of European countries. ${ }^{41}$ With the amendment of the Protection of Documents and Archives and Archival Institutions $\mathrm{Act}^{42}$ of 2014, the archival materials, acquired by the archives before the formation

38 Dragan Matić, "Stanje varstva arhivskega in dokumentarnega gradiva na slovenskih ministrstvih," in: Tehnični in vsebinski problemi klasičnega in elektronskega arhiviranja, 275-85.

39 ZVDAGA, Article 92 (from EUR 2000 to EUR 5000).

40 Kersten Jedlitschka, "Arhiv Stasija - preteklost in sedanjost," in: Primeri različnih praks v slovenskih arhivih: 25. zborovanje, eds. Zdenka Bonin and Marjan Vogrin (Ljubljana: Arhivsko društvo Slovenije, 2011), 19-31.

41 Everyone is also allowed to take digital photos of the archival materials free of charge.

42 ZVDAGA, Article 65. 
of the Assembly of the Republic of Slovenia on 17 May 1990, became accessible in their entirety - including the materials labelled with various levels of inaccessibility. Regarding these materials the archives only provide for the protection of personal data related to health status; sexuality; victims of crimes against sexual inviolability, matrimony, family and youth; perpetrators of crimes and offences except for the crimes and offences committed by persons prosecuted for opposing the one-party regime; as well as religious belief and ethnic adherence. ${ }^{43}$ The documents containing the aforementioned data shall become accessible 75 years after their creation or 10 years after the death of the concerned individual, if the date of death is known and unless otherwise stipulated by other laws. ${ }^{4}$ The Government of the Republic of Slovenia can also grant claimants access to these materials on the basis of the prior opinion of the archival commission. ${ }^{45}$

\section{The Attitude of the State and Its Policies towards the Archives and Archival Materials as a Cultural Monument}

The archival materials related to the formation of the Slovenian state in the historical period when Slovenians finally became a nation with their own independent and sovereign state represent a national treasure of the highest degree and are of exceptional importance for the preservation of national identity. The experience of the archival science demonstrates that people who have led this country since its establishment have not been sufficiently aware of this fact.

The archives have not acquired any new buildings in 25 years, and the national archives have been waiting for almost as long for the renovation of the old barracks near the Poljanska cesta street. ${ }^{46}$ The attitude towards archives, demonstrated by other countries that share a similar destiny, is substantially different. For example, Slovakia and the Czech Republic ${ }^{47}$ have built completely new archives where they can preserve their national treasure.

Archival legislation, adopted in 2006, represented a severe impediment for the development of the archival science as well. It significantly increased the jurisdictions of the national archives in the field of digital materials without ensuring enough suitably-trained staff to carry out these tasks. The flawed legislation, which was not written by the archival science at the time, later resulted in two referendums. For this

43 Bojan Cvelfar, "O dostopnosti arhivskega gradiva $\mathrm{v}$ javnih arhivih pred in po uveljavitvi ZVDAGA-A,» in: Arbivi na razpotju: 27. zborovanje, ed. Jure Volčjak (Ptuj: Arhivsko društvo Slovenije, 2015), 8-17.

44 Vanja Pfajfer and Gregor Jenuš, "Novela ZVDAGA - korak naprej? Dostop do arhivskega gradiva z osebnimi podatki doma in na tujem," in: Arhivi na razpotju, 18-29.

45 Igor Omerza, "Stališče z vidika uporabnika: Novela arhivskega zakona - kratka predzgodovina in posledice,» in: Arhivi na razpotju, 33.

46 Jedert Vodopivec, "Analiza stanja v slovenskih javnih arhivih," in: Arhivski depoji v Sloveniji, ed. Jedert Vodopivec (Ljubljana: Arhiv Republike Slovenije, 2008), 9-32.

47 Jozef Hanus and Emília Hanusová, "Archival building - the basic condition for proper functioning of the archives," in: Tehnični in vsebinski problemi klasičnega in elektronskega arbiviranja, 217-24. 
reason we had to focus on political issues ${ }^{48}$ for quite a few years instead of solving the professional archival challenges brought about by the digital age and the rapid development of various new technologies.

After all, in the last twenty-five years archives have played an exceedingly important role. They were part of momentous processes, resulting from the emancipation and the change of the social order. The archival materials kept in the archives became extremely important for proving the rights of the state and individuals during the implementation of the legislation on denationalisation, righting the injustices suffered by the victims of wartime and post-war violence, etc. However, the archival science has not taken adequate advantage of this situation, as it has failed to ensure the deserved position for the national archives in the Republic of Slovenia.

\subsection{Frequent restructuring of the public administration endanger archival materials}

The very frequent restructuring of the public administration represents a severe danger for the archival materials kept by the state authorities, including those attesting to the democratisation and the formation of the state. In the last few years individual state bodies were abolished and re-established, while their duties were redistributed among the administrative bodies. This resulted in the documentary and archival materials being moved between locations. Every disorganised relocation represents an extreme risk for these materials. They can get mixed up; the initial arrangement is not preserved; they can get lost or even destroyed. Furthermore, all of the above results in huge financial expenses for repeated arrangement and description, while considerable compensations may result from the individual proceedings conducted by the administrative bodies in case of loss or destruction of the materials.

Archival materials, created in digital form, are subject to an even greater risk as the materials on classic media. The latter may always be rearranged and described, which is what the creators of archival materials are doing for a number of years before submitting the archival materials to the archives. On the other hand, in case of digital materials inappropriate storage may result in complete loss in a single reckless moment, if these materials are not handled properly ever since their creation. ${ }^{49}$

In certain cases the practice to date has turned out to be extremely inappropriate. Therefore every newly-formed government should precisely and unambiguously define the handling of documentary and consequently also archival materials since their very creation and during every subsequent restructuring. Moreover, suitable facilities for the storage of these materials for at least thirty years should be ensured. Perhaps this could also be achieved by designating the facilities for the storage of

48 Dragan Matić, "Arhivska javna služba med politiko in stroko," in: Primeri različnih praks v slovenskih arhivih, 7-18.

49 Tatjana Hajtnik, Celovit pristop k pretvorbi elektronskih dokumentov v obliko za dolgoročno hrambo (Maribor: Fakulteta za elektrotehniko, računalništvo in informatiko, 2016), 145. 
permanent collections (archives), where these materials could be kept until their submission to the competent archives, similarly as this matter is arranged in Austria, Germany, and in certain other EU countries.

\section{In Place of Conclusion}

Archival materials are already waiting for the researchers of all aspects of historiography and other sciences and attracting them to the archives. Every analysis of the contemporary archival materials calls for great enthusiasm, professionalism, and especially impartiality. The events and individual documents should be highlighted with all the accessible sources and from all angles, despite the historical distance of merely a quarter of a century. In order to underline the above, let me refer to the analysis of an extremely important document, signed on 6 December 1990 in the Assembly of the Republic of Slovenia by all the political parties and groups of delegates. On the same day the delegates passed the Plebiscite on the Sovereignty and Independence of the Republic of Slovenia Act with an overwhelming majority. I am referring to the Agreement of the Political Parties and Groups of Delegates of the Assembly of the Republic of Slovenia on the Joint Action at the Plebiscite on the Sovereignty and Independence of the Republic of Slovenia. The parties and groups of deputies agreed on thirteen points, stated on three pages. The responsible representatives of the parties and groups signed the last page of the document. As the names and surnames of the signatories were not recorded on a single document, not all of them are still discernible today - only twenty-five years later. Meanwhile, the name and surname ${ }^{50}$ of one of the signatories of the Agreement, stated on the cover or folder that contains the document, is wrong. Thus the error, which had already been published in literature beforehand, was only discovered at the twenty-fifth anniversary of the signing of this Agreement by subsequently checking the television recordings and oral testimonies of the signatories of the Agreement. The lack of historical distance is not always negative: in this concrete case it turned out to be very useful for fixing the inadvertent mistake.

\section{Sources and Literature}

Archive sources:

- SI AS, Arhiv Republike Slovenije:

- SI AS 142 - Republic Electoral Commission, 1963-2000.

o SI AS 223 - Government of Slovenia, 1945-1992.

o SI AS 316 - Agency for the Audit of the Ownership Transformation of Companies, 19932004.

o SI AS 1115 - Assembly of Slovenia, 1943-1990.

- SI AS 1116 - Ministry of Finance, 1945-1993.

o SI AS 1210 - The collection on plebiscite of 1990.

o SI AS 1211 - Commission for Relations with Religious Communities, 1953-1991.

o SI AS 1214 - Social Accounting Service, 1947-2002.

50 The name Vitomir Gros was stated for the Liberal Party instead of Franc Golija. 
- SI AS 1233 - Republic Committee for Agriculture, Forestry and Food of the Socialist Republic of Slovenia, 1972-1991.

o SI AS 1265 - Republic Committee for Industry and Construction of the Socialist Republic of Slovenia, 1965-1991.

o SI AS 1944 - Presidency of Slovenia, 1974-1990.

- SI AS 2003 - Ministry of Education, Science and Sport of the Republic of Slovenia, 1967-2004.

- SI AS 2046 - Office of the Government of the Republic of Slovenia for National Minorities, 1974-2012.

- $\quad$ SI AS 2053 - Court of Audit of the Republic of Slovenia, 1987-2003.

- SI AS 2055 - Protocol Service of the Republic of Slovenia, 1945-1991.

o SI AS 2057 - Government of the Republic of Slovenia Public Relations and Media Office, 1972-2001.

- SI AS 2089 - Ministry of Economic Relations and Development, 1994-2002.

- SI AS 2113 - Office of the Republic of Slovenia for Immigration and Refugees, 1957-2010.

- SI AS 2115 - Ministry of Transport and Communications, 1975-1996.

o SI AS 2120 - Council for the Protection of Human Rights and Fundamental Freedoms, 19871995.

- SI AS 2026 - Ministry of Education and Sport of the Republic of Slovenia, 1982-2003.

- SI AS 2033 - Slovenian Research Agency, 1986-2005.

- SI AS 2079 - Slovenian Roads Agency, 1967-2008.

o SI AS 2133 - Farmland and Forest Fund, 1918-2014.

- ZVDAGA, Protection of Documents and Archives and Archival Institutions Act, Official Gazette of the Republic of Slovenia, No. 30/06, 51/14.

Note: In the archival science, the materials in fonds are referred to as SI AS and the number of fonds or collection. ARS is the old code for the current AS. SI is the code for Slovenia.

Further examples of references to the fonds and collections of other archives: e.g. SI ZAC (Celje Historical Archives), SI ZAL (Ljubljana Historical Archives), SI PAK (Koper Regional Archives).

\section{Literature:}

- Bućin, Rajka. Klasifikacijski sustavi u spisovodstvu uprave. Povijesni razvoj i suvremena stremljenja. Zagreb: Hrvatski državni arhiv, 2015.

- Cvelfar, Bojan. "O dostopnosti arhivskega gradiva v javnih arhivih pred in po uveljavitvi ZVDAGA-A.” In: Arhivi na razpotju: 27. zborovanje, ed. Jure Volčjak, pp. 8-17. Ptuj: Arhivsko društvo Slovenije, 2015.

- Hajtnik, Tatjana. Celovit pristop k pretvorbi elektronskih dokumentov v obliko za dolgoročno hrambo. Maribor: Fakulteta za elektrotehniko, računalništvo in informatiko, 2016.

- Gotovina, Vesna. "Sistemi poslovanja s spisi v Sloveniji od leta 1955 dalje." Arhivi 16, No. 1-2 (1993): 45-54.

- Hanus, Jozef and Hanusová Emília. "Archival building - the basic condition for proper functioning of the archives." In: Tehnični in vsebinski problemi klasičnega in elektronskega arhiviranja, pp. 217-26. Radenci, 2011.

- Jedlitschka. Kersten. "Arhiv Stasija - preteklost in sedanjost." In: Primeri različnih praks v slovenskih arhivih: 25. zborovanje, eds. Zdenka Bonin and Marjan Vogrin, pp. 19-31. Ljubljana: Arhivsko društvo Slovenije, 2011.

- Matić, Dragan. "Arhivska javna služba med politiko in stroko." In: Primeri različnih praks v slovenskih arhivih: 25. zborovanje, eds. Zdenka Bonin and Marjan Vogrin, pp. 7-18. Ljubljana: Arhivsko društvo Slovenije, 2011.

- Matić, Dragan. "Stanje varstva arhivskega in dokumentarnega gradiva na slovenskih ministrstvih." In: Tehnični in usebinski problemi klasičnega in elektronskega arhiviranja, pp. 275-85. Radenci, 2007.

- Omerza, Igor. "Stališče z vidika uporabnika: Novela arhivskega zakona - kratka predzgodovina in posledice." In: Arhivi na razpotju: 27. zborovanje, ed. Jure Volčjak, pp. 30-35. Ptuj: Arhivsko društvo Slovenije, 2015. 
- Pfajfer, Vanja and Gregor Jenuš. "Novela ZVDAGA - korak naprej? Dostop do arhivskega gradiva z osebnimi podatki doma in na tujem." In: Arhivi na razpotju: 27. zborovanje, ed. Jure Volčjak, pp. 18-29. Ptuj: Arhivsko društvo Slovenije, 2015.

- Vodopivec, Jedert. "Analiza stanja v slovenskih javnih arhivih." In: Arhivski depoji v Sloveniji, ed. Jedert Vodopivec, pp. 9-32. Ljubljana: Arhiv Republike Slovenije, 2008.

- Žumer, Vladimir. "Klasifikacijski načrti za razvrščanje dokumentacije z roki hranjenja." In: Tehnični in vsebinski problemi klasičnega in elektronskega arhiviranja, eds. Ivan Fras and Nina Gostečnik, pp. 353-68. Radenci, 2013.

- Žumer, Vladimir. Poslovanje z zapisi. Upravljanje in hramba dokumentarnega gradiva, klasifikacijski načrti za razvrščanje gradiva z roki hrambe in elektronska hramba gradiva v digitalni obliki. Ljubljana: Planet GV, 2008.

$\frac{\text { Vesna Gotovina }}{2 \text { ARHIVSKO GRADIVO DRŽAVNIH ORGANOV O PROCESIH DEMOKRATIZACIJE IN }}$
OSAMOSVAJANJA SLOVENIJE
P O V ZE T E K

Namen prispevka je predstavitev varstva arhivskega gradiva najpomembnejših državnih organov, ki je nastalo v procesih demokratizacije in osamosvajanja Slovenije.

Arhivsko gradivo je dokumentarno gradivo, ki ima trajen pomen za zgodovino, druge znanosti in kulturo ali trajen pomen za pravno varnost oseb; arhivsko gradivo je kulturni spomenik. Najpomembnejše naloge arhivske stroke in arhivistov, ki se ukvarjajo z novejšim arhivskim gradivom so tudi vrednotenje, prevzemanje in ohranjanje arhivskega gradiva o procesih demokratizacije in osamosvajanja Slovenije. Bliža se 30 letni rok za izročitev arhivskega gradiva, zato na nekaterih najpomembnejših državnih organih že danes potekajo vsi potrebni in zakonsko predpisani postopki (urejanje, odbiranje, popisovanje, tehnično opremljanje..) za predajo arhivskega gradiva v Arhiv RS.

Veliko arhivskega gradiva državnih organov iz obdobja konca osemdesetih in začetka devetdesetih let prejšnjega stoletja, je že danes shranjenega v nacionalnem arhivu. Med najpomembnejše arhivske fonde in zbirke lahko štejemo naslednje: Vlada Republike Slovenije (1945 do 1992), Skupščina Slovenije (1943 do 1990), Predsedstvo Slovenije (1974 do 1990), Republiška volilna komisija (1963 do 2000), Zbirka plebiscit 1990, Urad Vlade RS za informiranje (1972 do 2001), Protokol RS (1945 do 1991), Urad Vlade RS za narodnosti (1974 do 2012), Svet za varstvo človekovih pravic in temeljnih svoboščin (1987 do 1995). Znanstveniki, raziskovalci in drugi uporabniki lahko že danes na izvirnih arhivskih virih preučujejo različna področja življenja in dogodkov enega najpomembnejših zgodovinskih obdobij na teritoriju današnje Republike Slovenije. Gradivo prevzeto v arhive omogoča raziskovanje politične, gospodarske, socialne, šolske... zgodovine ter pomembnih procesov - npr. spremembe družbene ureditve, uvedbe večstrankarskega sistema, postopkov denacionalizacije in privatizacije družbene lastnine.

Dostop do arhivskega gradiva $v$ arhivih določa arhivska zakonodaja. Ta opredeljuje varovane osebne podatke in določa roke nedostopnosti, in sicer 75 letni od nastanka dokumenta ali 10 letni po smrti osebe na katero se nanašajo podatki. $V$ arhivih niso 40 let dostopni tajni podatki, ki jih morajo javnopravne osebe, ki izročajo tovrstno arhivsko gradivo ob izročitvi natančno opredeliti. Vlada RS imenuje Arhivsko komisijo, ki na podlagi vloge raziskovalca ali raziskovalne inštitucije lahko odobri dostope tudi do omenjenega gradiva.

Arhivsko gradivo, ki je še vedno shranjeno pri ustvarjalcih in imetnikih, ogrožajo tudi nekateri dejavniki, na katere arhivska stroka ves čas opozarja. To so predvsem zelo pogoste reorganizacije uprave. Predpisi ob samih reorganizacijah ne opredeljujejo natančnih postopkov ravnanja z dokumentarnim in arhivskim gradivom ob razdružitvah, združitvah ali ukinitvah posameznih organov. Največja nevarnost, ki ogroža arhivsko gradivo, so neustrezni prostori za hrambo arhivskega gradiva tako pred prevzemom $\mathrm{v}$ arhive, kot tudi kasneje. V Sloveniji se večina arhivov srečuje s problematiko pomanjkanja ustreznih arhivskih prostorov. 